\title{
INTERPERSONAL MEANING IN JOKOWI'S SPEECH A CASE STUDY at SUMMIT APEC
}

\author{
Firmansyah Nursyamsi, Arry Purnama and Hartono. \\ English Department, Faculty of Letters, Al-Ghifari University, Jl. A.H. Nasution- \\ Sukamiskin no.247, Bandung, 40293, Indonesia \\ nursyamsifirmansyah@gmail.com
}

\begin{abstract}
ABSTRAK: Studi ini berkaitan dengan analisis bahasa yang digunakan untuk komunikasi. Studi ini menganalisis pidato Jokowi di SUMMIT APEC, Beijing dari perspektif SFL terutama dengan sistem mood dan modality. Dengan kata lain, penelitian ini tentang makna interpersonal dari pidato yang dapat digunakan untuk menggali sikap dan penilaian pembicara terhadap apa yang dikatakan dalam pidato. Dalam melakukan penelitian ini, ada dua tujuan yang ingin dicapai. Pertama, penelitian ini mencoba untuk mendeskripsikan makna dari pidato Jokowi berdasarkan makna interpersonal dengan melihat secara mendalam pada sistem mood. Kedua, penelitian ini juga mencoba mendeskripsikan bagaimana Jokowi memengaruhi audiensi melalui makna interpersonal dengan melihat secara mendalam system modality. Dalam pidato Jokowi ada 94 data yang ditemukan oleh peneliti. Data itu sendiri direalisasikan dengan sistem mood yang terbagi menjadi 78 data deklaratif, 1 data interogatif, dan 15 data imperatif. Hasil analisis menunjukkan bahwa Jokowi kebanyakan menggunakan deklaratif. Jokowi menggunakan deklaratif karena ia ingin berbagi informasi kepada audiensi melalui pidatonya. Informasi yang dibagikan sebagian besar tentang investasi. Jokowi ingin para audiensi atau investor untuk berinvestasi di Indonesia. Selain itu, modality dalam pidato Jokowi kebanyakan menggunakan inclination. Berdasarkan data yang telah dianalisis melalui modality, peneliti menemukan 29 data dalam pidato Jokowi. Data itu sendiri dibagi menjadi 1 data usuallity, 12 data obligation, dan 16 data inclination. Inclination terjadi ketika seseorang memiliki keinginan untuk melakukan sesuatu untuk orang lain. Artinya, Jokowi menggunakan inclination untuk mempengaruhi audensi. Inclination digunakan Jokowi untuk mengungkapkan keinginannya. Jokowi ingin audiensi untuk berinvestasi di Indonesia.
\end{abstract}

Kata kunci: Makna Interpesonal, Mood, Modality, Jokowi

ABSTRACT: This study deals with analyzing language used for communication. It analyzed Jokowi's speech at SUMMIT APEC, in Beijing from the perspective of SFL 
especially dealing with system of mood and modality. In other words, this study is about interpersonal meaning of the speech which can be used to dig up speaker's attitudes and judgments towards what s/he is saying in the speech. In conducting this study, there are two objectives to achieve. The first, this study tried to describe the meaning of Jokowi's speech based on interpersonal meaning by looking deeply on the mood system in Jokowi's speech. The second, it also tried to describe how Jokowi influences the audiences through interpersonal meaning by looking deeply on modality. In Jokowi's speech there are 94 data that found by the researcher. The data itself is realized by system of mood that divided into 78 data of declarative, 1 data of interrogative, and 15 data of imperative. The result of analysis showed that Jokowi mostly useD declarative. Jokowi used declarative because he wanted to share information to the audiences by delivering his speech. The information which is shared is mostly about investment. Jokowi wants the audiences or investors to invest in Indonesia. Besides that, based on data that has been analyzed through modality, the researcher found 29 data in Jokowi's speech. The data itself divided into 1 data of usuallity, 12 data of obligation, and 16 Inclination. In Jokowi's speech, Jokowi mostly used inclination. Inclination occurs when someone has desire to do something for others. It means, Jokowi used inclination to influences the audiences. Inclination itself used to Jokowi to express his wishes. Jokowi wanted an audiences to invest in Indonesia.

Keywords: Interpersonal Meaning, Mood System, Modality, Jokowi

\section{Introduction}

Communication, like delivering a speech in front of publics, has become important part of our lives and one important thing deals with communication itself is language. Language, either spoken or written, holds an important role in human everyday life. People use language in every kind of context, condition, or situation; it is used to express some feelings, describe some objects, or tell something. According to Halliday (1994:17), language is a system for making meanings; a semantic system, with other systems for encoding the meanings it produces.

Furthermore, Bloomer et al., (2005:79) added that, language is meaningful, when the meaning is conveyed though language, people use language to interact and establish relations, to influence their behavior and expressions of the word. It means of conveying a messages to others. So, without language it is hard to imagine how people can cooperate and get along with one another and language cannot be separated from human life since it is a means a communication. It 
is understandable that language is very functional in communication.

Moreover, language is not only used to communicate every day, but also used for political tools. The important people like the president uses language to communicate through speech. Public speeches are delivered orally, which are often well-prepared in writing and presented on formal occasions. Based on the functions and contents, political speech is a kind of public speech given by authorities with political purposes that tries to influence a certain group of people. They deliver their speeches in front of audiences.

Based on explanation above, the researcher uses speech given by president Jokowi at SUMMIT APEC in Beijing as the data under scope Systemic Functional Linguistics. Systemic Functional Linguistics (SFL) is a theory of language in which language function becomes the center of discussion. This theory was developed by Halliday and it is named as Systemic Functional Linguistics (SFL). The perspective of SFL, language is viewed as a system for making meanings: a semantic system, with other systems for encoding the meaning it produces (Halliday, 1994:17).

In the scope of Systemic Functional Linguistics, there are fundamental components of meaning called Metafunction. According to Halliday (1985:13), the functional components are ideational metafunction, interpersonal metafunction and textual metafunction. Halliday (1994:68) added that through the interpersonal metafunction that people establish, negotiate and assume their position in social relationship, and it is concerned with clauses as exchange. The interpersonal meaning begins with defining basic speech role: giving information, giving goods-andservices and demanding goods-andservices, respectively called statement, questions and commands (Halliday, 1994:68).

Therefore, the researcher chose Jokowi's speech because two reasons. The first reason is dealing with the figure of Jokowi itself. Jokowi is the seventh president of Republik Indonesia. He is the current president of Republik Indonesia after winning the general election of 2014. Starting his political carrier as the Mayor of Solo on 2005, he started to gain the public trust with his ways of managing, organizing, and leading his city. His simple, flexible, and sociable attitudes become his personal excess which differentiates him with the other politicians.

Therefore, his image as the leader that is close his people adheres firmly in people's mind. Quickly, he grows into a famous politician who is known and admired by many people. This factor then escalates his political carrier rapidly. Soon, on 2012, he became the 
Governor of Jakarta, the capital city of Republik Indonesia. With his popularity and integrity, he only needs two years to achieve the position which most politicians want; he became the president of Republik Indonesia on 2014 after struggling and winning the general election of 2014 against his rival Prabowo Subianto. Considering the rapid escalation of his political carrier and his well integrity, Jokowi is also considered as a phenomenal president of Republik Indonesia.

The second reason, Jokowi is included in the list of influential figures in the world. Jokowi is on the list of 100 influential figures in the world in 2018. Based on the business and financial magazine of the United States, Forbes, Jokowi is ranked 74th influential figure in 2018. Jokowi is the only influential Indonesian in the world in 2018.

Based on some reasons explained in the background of the study above and to make this research easier to solve, the researcher studies the particular problems as stated below:

How is the meaning of Jokowi's speech based on interpersonal meaning?

\section{THEORITICAL FOUNDATION}

Systemic Functional Linguistics is a study of language which focuses on language as a resource of meaning. This theory is introduced by M.A.K Halliday by using discourse analysis. It views language primarily as a resource for exploring and understanding the meaning in discourse (Halliday, 1994: 15). It is different from any other theory of language since it has both systematic and functional in it is characteristic.

Systemic Functional Linguistics theory is a theory of meaning as choice, by which a language or any other semiotic system is interpreted as networks of interlocking options (Halliday, 1985: 16). It is also a functional one because the conceptual framework on which it is based is a functional rather than a formal one. It is based on the conceptualization of language as a resource of meaning rather than on the conceptualization of language as a system of rules.

The fundamental components of meaning in language are functional components. Halliday (2002: 198) introduces three functional modes of meanings of language from the point of the semantic system: (1) ideational (2) interpersonal and (3) textual.

This study the researcher only use interpersonal meaning as functional component. Gerot and Wignell (1994:13) explain that interpersonal meanings are meanings which express a speaker s attitudes and judgments. These are meanings for acting upon and with others. Meanings are realized in wordings through what is called mood and modality. Meanings of this kind are most centrally influenced by tenor of discourse. Moreover, Lock explains about interpersonal meaning. 
Lock (1996:9) explains that: Interpersonal meaning has to do with the way in which we act upon one another through language-giving requesting information, getting people to do things and offering to do things ourselves and the way in which we express our judgment and attitudes about such things as likelihood, necessity, and desirability.

While Martin, Matthiessen, and Painter (1997:5) state interpersonal meaning involves treating the text dialogue basically this means dividing the text into things you can argue with. Interpersonal meaning views language from point of views of its function in the process of social interactions.

Interpersonal meaning, according to Butt (2001:86) is one of the most basic interactive distinction is between using language to exchange information and using it to exchange goods and services. These meanings are most centrally influenced by tenor (who/what kind of person produced this text? For whom?) of discourse.

Interpersonal meanings focus on the interactivity of the language, and concern the ways in which we act upon one another through language. In either spoken texts or written texts, an interlocutor expects to tell listeners/readers via text. It means that each text has a relationship between providers and recipients of information. Interpersonal meaning also deals with three components, are mood element, residue element, and mood system. The mood element includes subject, finite, and/or mood adjunct; while the residue consists of predicator, complement, and some adjuncts such as mood, polarity, comment, vocative or circumstantial adjunct (Eggins, 1994:154-169).

\section{METHODOLOGY}

This research used descriptive qualitative method. The researcher of this study attempt to describe the meaning of Jokowi's speech at SUMMIT Apec. According to Sutrisno Hadi (1983: 3) states that collecting the data, classifying the data, analyzing the data, interpreting the data, and finally drawing conclusion without making generalization carry out descriptive method. Narbuko and Achmadi (1997: 44) also state that a descriptive method is a research method which tries to give the solution of a problem based on the data. In this research, the researcher used indirect observation technique, video, script, and Internet to get text of Jokowi's speech in Summit Apec.

\section{Result and Discussion}

The Meaning of Jokowi's speech Based on Interpersonal Meaning. The researcher concluded that the meaning Jokowi's speech based on interpersonal meaning can be seen through mood system. Therefore, the researcher analyze Jokowi's speech through mood system. The mood system itself consists 
of declarative, interrogative and below can explain how the meaning imperative. In Jokowi's speech, the Jokowi's speech based on mood researcher found 94 data. The table system.

\begin{tabular}{|l|l|}
\hline $\begin{array}{l}\text { The Mood System in Jokowi's } \\
\text { Speech }\end{array}$ \\
\hline Declarative & 78 \\
\hline Interrogative & 1 \\
\hline Imperative & 15 \\
\hline
\end{tabular}

The table above, the most dominant in the mood system is declarative. Jokowi used declarative because Jokowi's position is the same or parallel with the listener. So, the sentence used is declarative. It means, in Jokowi's speech, the relationship between the speaker (Jokowi) and the listener (audiences) is the speaker (Jokowi) as the provider of information and the listener (audiences) as the recipient of the information. The meaning of Jokowi's speech based on interpersonal meaning itself can be seen from the Jokowi's way builds his pattern of communication with listeners.

3.1.1. The Communication Patterns Built by Jokowi on Audiences

DATA 4

Today, I am happy.
Based on the data that given by the researcher, it shows that Jokowi used declarative to communicate on audience. Jokowi mostly used declarative because he built his position is the same level with the audiences. It means, declarative used to Jokowi to build the communication with the audiences and Jokowi' position is the provider of information and the audiences as the recipient of the information.

The followings are the examples data of the interpersonal meaning analysis in the Jokowi's speech that is realized by declarative mood. The table below also shows the way of Jokowi to build the communication patterns on audiences.

\begin{tabular}{|l|l|l|l|}
\hline Today & I & am & happy \\
\hline Cir.A & S & F & C \\
\hline \multicolumn{3}{|c|}{ Residue } \\
\cline { 2 - 3 }
\end{tabular}

DECLARATIVE 
The mood structure above, it can be found that there are only one clause in a sentence. The clause is a statement. This statement can be identified by the position of the subject (I) which is before the finites (am), complement (happy) and (today) as a circumstantial adjunct

\subsubsection{The Meaning of Jokowi's Speech} Based on The Communication Patterns

As the researcher explained before, in Jokowi speech the researcher found 94 data. The data itself divided into declarative 78 data, interrogative 1 data, and for imperative 15 data. So, based on the communication patterns that Jokowi built, the researcher concluded that Jokowi used declarative in his speech. It means, Jokowi's position is the same or parallel with the listener. So, the sentence used is declarative. In the declarative can be seen the meaning Jokowi's speech based on the communication patterns.

In Jokowi's speech, Jokowi not only used declarative in his speech, but also he used interrogative and imperative. The data below explained that there are not only declarative that Jokowi built to communicate on audiences but also Jokowi used interrogative and imperative.

In Jokowi's speech, the researcher have analysed 78 data of declarative but in this chapter represents 10 data of declarative. The data itself can be seen below:

DATA 9

The picture shows you our maps of Indonesia.

\begin{tabular}{|l|l|l|l|l|}
\hline The picture & \multicolumn{2}{|l|}{ shows } & you & $\begin{array}{l}\text { our maps of } \\
\text { Indonesia }\end{array}$ \\
\hline S & F & P & C & Cir.A \\
\hline Mood & \multicolumn{4}{|l|}{ Residue } \\
\hline
\end{tabular}

\section{DECLARATIVE}

The mood structure above, it can be found that there are only one clause in a sentence. The clause is a statement. This statement can be identified by the position of the subject (The picture) which is before the finites or predicator (shows), complement (you) and (our maps of Indonesia) as a circumstantial adjunct.

In this statement, the word (the picture) is a subject. The word (the picture) refers to the map of Indonesia. The relationship between the speaker (Jokowi) and the hearer (audiences) is the speaker (Jokowi) as the provider of information and the hearer (audiences) 
as the recipient of the information. It means that the clauses of the Jokowi's speech are giving or demanding information to the listeners or readers. Jokowi gave the information and explained about the map of Indonesia to the audiences.

The data below will explains Jokowi's position build communication with interrogative.

DATA 52

What is sea toll?

\begin{tabular}{|l|l|l|}
\hline What & is & sea toll? \\
\hline WH & F & C \\
\hline Mood & & Residue \\
\hline
\end{tabular}

INTERROGATIVE - WH-question

The mood structure above, it can be found that there are only one clause in a sentence. The clause is a question. It can be identified by the position of the subject (what) which is after the finite (is) and (sea toll?) as a complement.

In this question is Jokowi itself as a speaker. The relationship between the speaker (Jokowi) and the hearer (audiences) is the speaker (Jokowi) as the recipient of the information and the hearer (audiences) as the provider of information. Jokowi demands the audiences to respond his opinion about DATA 1

Ladies and gentlemen, all CEOs, good morning. sea toll. Sea toll here refers to maritime transportation system to make transportation cost lower and more efficient.

Based on data that the researcher have analyzed, Jokowi only one used interrogative in his speech. It means, Jokowi's position is the recipient of the information and audiences as the provider of information. Jokowi not much used interrogative because in his speech Jokowi as a speaker.

The data below will explains Jokowi's position build communication with imperative.

$$
\begin{aligned}
& \text { Ladies and gentlemen, all CEOs, good } \\
& \text { morning. }
\end{aligned}
$$


IMPERATIVE

The mood structure above is imperative. It can be identified there are subject only. In this clause, Jokowi expressed his attitude to the audiences by giving opening remarks addressed to audiences.

Based on data that the researcher have analyzed, the researcher found 15 data of imperative. In Jokowi's speech, Jokowi mostly used imperative to express instruction to the audiences. Jokowi not much used imperative in his speech because Jokowi's position is the same or parallel with the listener. So, the sentence used is imperative.

\section{CONCLUSIONS}

Based on the findings and the discussion, the meaning Jokowi's speech based on interpersonal meaning can be seen from the way Jokowi builds a pattern of communication with listeners through the way Jokowi positions himself same with the level of the listener. Jokowi's position is the same or parallel to the listener, then, the sentence used is declarative. In Jokowi's speech, the researcher found 94 data. The data 94 itself divided into: Declarative 78, Interrogative 1, and for Imperative is 15 . Jokowi mostly used declarative because Jokowi wanted to share information to the audiences by delivering his speech. The information which is shared is mostly about investment. 


\section{BIBLIOGRAPHY}

\section{Printed References}

Arikunto, S. 2002. Prosedur Penelitian: Suatu Pendekatan Praktek. Jakarta: Rineka Cipta.

Bloor, Thomas and Bloor, Meriel. 2004. The Functional Analysis of English. London: Arnold.

Butt, d, (et. al.). 1995. Using Functional Grammar. Sydney: National Centre for English Language, Teaching and Research.

Buttt, D., Fahey, R., Feez, S. 2003. Using Functional Grammar-- An Explorer's Guide. Sydney: National Centre for English Language Teaching and Research.

Derewianka, Beverly. 1990. Exploring How Texts Work. ....?

Deterding, David and Poedjosoedaro, Gloria. 2001. English Grammar. New York: Routledge.

Eggins, S. 1994. An Introduction to Systemic Functional Linguistics. London: Pinter Publishers Ltd.

Eggins, S. (2010) An Introduction to Systemic Functional Grammar. London: Continuum.

Gerot, L. And Wignell, P. 1994. Making Sense of Functional Grammar. Sidney Antipodean Educational Enterprise (AEE).

Hadi, S. 1983. Methodology Research. Yogyakarta: Yayasan Penerbitan Fakultas Psikologi, Universitas Gadjah Mada.

Halliday, M.A.K. 1985. An Introduction to Functional Grammar. London: Edward Arnold Inc.

Halliday, M.A.K. 1994. An Introduction to Functional Grammar (second edition) London: Edward Arnold Inc.

Halliday, M.A.K. 2002. An Introduction to Functional Grammar. Beijing: Foreign Language

Halliday, M.A.K. 2004. Introduction to Functional Grammar. London: Edward Arnold.

Hammond, Jenny. et al. 1992. English for Social Purposes. Sydney: Macquarie University

Hornby, A.S. 2003. Oxford Advanced Learner's Dictionary. New York: Oxford University Press.

John W. Creswell. 2009. Research Design: Qualitative, Quantitative, and Mixed methods Approaches. Newbury Park: Sage Productions

Lehtonen,M. 2000. Cultural Analysis Of Texts. London: SAGE publication Ltd.

Lock, Graham. 1996. Functional English Grammar, USA: Cambridge University Press. Martin, J.R. 1992. English Text: System and Structure. Amsterdam: The Netherlands: John Benjamins B.V.

Martin, J.R., Matthiessen, C. M. \& Painter, C. (1997). Working with Functional Grammar. London: Arnold. 
Matthiessen, C. , Lam, M., \& Teruya , K. (2010). Key terms in systemic functional linguistics. London: Continuum International Publishing Group.

Moleong, LJ 1990. Metodologi Penelitian Kualitatif. Bandung: Remaja Rosdakarya.

Narbuko, Cholid, \& Abu Achmadi. 1997. Metodologi Penelitian. Jakarta: Bumi Ak sara.

Sugiyono, Metode penelitian administrasi, Alfabeta, Bandung, 2004.

Memahammi Penelitian Kualitatif, Alfabeta, Bandung, 2005.

Sujatna, Eva Tuckyta Sari. 2003. Komplemen Subjek dan Ko dalam Klausa Bahasa Inggris dan Padanannya Bahasa Indonesia, Bandung: Pasca Sarjana UNPAD

Sujatna, Eva Tuckyta Sari 2008a. Tata Bahasa Fungsional, Bandung: Uvula Press.

Sujatna, Eva Tuckyta Sari 2008b. English Syntax for Beginners: Revised edition, Bandung Uvula Press.

Sujatna, Eva Tuckyta Sari 2013. Understanding Systemic Functional Linguistics. Unpad Press.

White, P. R. R. 2000. Functional Grammar. Birmingham: University of Birmingham.

Young, L., \& Harrison, C. 2004. Systemic functional linguistics and critical discourse analysis. London: Continuum.

Yule, G. (2010) The Study of Language (4th Ed). Cambridge: New York.

\section{Journals}

Ayoola, Moses Olusanya. 2013. An Interpersonal Meaning Analysis of Some Selected Political Advertisements in Some Nigerian Newspapers International Journal of Humanities and Social Science. Vol 3: page 165-178. [March, 23rd, 2018]

Benjamin Netanyahu: full speech on Palestinian state. [August, 3rd, 2018]

Feng, H. \& Liu, Y. 2010. “Analysis of Interpersonal Metafunction in Public Speeches: A Case Study of Obama's Speech". Journal of Language Teaching and Research. Vol. 1. No. 6. pp. 825 -829. [March 30th, 2018]

Hakim, Lukman. Strategies of Constructing Appeals in Obama's Victory Speech. Semarang: [April, 16th, 2018]

Hastomo, Wisdiyan Hadi. 2011. The Interpersonal Meaning of Barack Obama's Speech Entitled "America Will Never Be at War with Islam". Semarang: : [April, 16th, 2018]

Nur, S. 2015. "Analysis of Interpersonal Metafunction in Public Speeches: A Case Study of Nelson Mandela's Presidential Inauguration Speech". The International Journals of Social Sciences. Vol. 30. No. 1. pp. 52 - 63. [February, 10th, 2018]

Wulandari, Dhiah Noor Aini. 2011. Interpersonal Meaning of BarackObama's Speech at University of Indonesia: The Study of Barack Obama's Attitudes and Judgments towards Indonesia. English Department Faculty of Languages and Arts Semarang State University [June, 27th, 2018]

Ye, R. 2010. The Interpersonal Metafunction Analysis of Barack Obama's. English Language Teaching. 146.www.ccsenet.org/elt. [April, 16th, 2018]

\section{Electronic References}


https://www.youtube.com/watch?v=Lo2jx_IFAoU

[January, 23rd, 2018]

http://www.telegraph.co.uk/news/worldnews/middleeast/israel/5535664/Benja minNetanyahu-full-speech-on-Palestinianstate.html

[August, 3rd, 2018 